Acta vet. scand. $1981,22,435-448$.

From the Department of Pathology, Veterinary College of Norway, Oslo.

\title{
PATHOMORPHOLOGY OF THE INTESTINAL MUCOSA IN DIARRHEIC CALVES*
}

\author{
By \\ Thor Landsverk
}

\begin{abstract}
LANDSVERK, T.: Pathomorphology of the intestinal mucosa in diarrheic calves. Acta vet. scand. 1981, 22, 435-448. - The intestinal mucosa was examined in twelve 2-5-week-old calves with a spontaneous intestinal disorder, 8 with diarrhea and 4 convalescents. The calves were fed a defined milk replacer. Light microscopy including morphometry, showed villous atrophy and crypt elongation. Villous epithelial cells had decreased height, and epithelial cells of the posterior small intestine contained an increased amount of fat droplets. Accumulation of neutrophils in crypts was frequent. Scanning electron microscopy revealed blunt villi with increased numbers of necrotic cells in the extrusion zone at the tips of the villi. The convalescents had generally milder changes, particularly in the anterior small intestine. The probable etiological factors included a rotavirus and chlamydial infection, and it is concluded that these agents together with other possible noxious influences were responsible for the increased necrobiosis of apical senescent villous epithelial cells, resulting in villous atrophy and crypt hyperplasia.
\end{abstract}

diarrhea; intestinal pathomorphology; villous atrophy; epithelial extrusion; rotavirus; chlamydia; calves.

Diarrhea in 2-6-week-old calves appears to be a serious problem in Norway. It has been suggested that calves at this age are especially susceptible to various diseases, since maternally derived immunoglobulins have then decreased to a minimum (Husband et al. 1978). Diarrhea in this age group seems, however, to have a very complex etiology, since a range of environmental, dietary and microbial factors may cooperate to establish the condition (Roy 1974, Appleman \& Owen 1975).

* This study was supported by grants from the Agricultural Research Council of Norway. 
A report to be published elsewhere (Landsverk et al. in prep.) describes microbiologic findings in spontaneous diarrhea of calves fed defined milk replacers. The purpose of the present report is to describe the pathomorphologic lesions in these calves. As infectious agents probably were of major importance in the development of the intestinal lesions, a brief description of the results of the microbiologic examinations is included.

\section{MATERIALS AND METHODS}

Animals and diets

The material comprises 12 calves affected with an intestinal disorder (calves 1-12) also used in other studies (Landsverk $1981 \mathrm{~b}, \mathrm{c}$, Landsverk et al. in prep.). Seven healthy calves, 13, 14, 17-21) served as controls. Calves $1-12$ were obtained from random farms and kept at the research station, Holt, while calves $13,14,17-21$ were kept throughout their lives at the research station, Heggedal. Calves 18-21 correspond to calves 1-4 in a previous paper (Landsverk 1979). All calves were conventionally reared with colostrum after birth and then whole cow's milk at a rate of $110 \mathrm{ml} / \mathrm{kg}$ body weight/day, twice daily. Calves 1-12 were continued on whole cow's milk for one week after their arrival at the Research Station. At 1-3 weeks of age calves 1-14 were introduced to milk replacers. The constituents of the replacers included equal amounts of skim milk and whey powder, without (diet B1, calves $1-6$, diet B3, calves 13,14 ) and with (diet B2, calves 7-12) heat damage, butter fat and vitamins. The composition of the replacers corresponds to that described in a previous paper (Laksesvela et al. 1978). The replacers were reconstituted with water at $35^{\circ} \mathrm{C}$ to $10,3 \%$ dry matter, and given at a rate as above. Further experimental details are given in the other study (Landsverk et al. in prep.). Some selected data are summarized in Table 1.

Sampling and processing of intestinal specimens

The calves were euthanized at different intervals from the start of the feeding on the milk replacers (Table 1). The procedures of sampling specimens have in part been described previously (Landsverk 1979). For calves on diet B1 and B2 the samples from the middle jejunum were taken randomly in the middle portion of the small intestine. With this exception the 
T a b l e 1. Experimental data on the calves.

\begin{tabular}{|c|c|c|c|c|c|c|}
\hline $\begin{array}{l}\text { Calf } \\
\text { No. }\end{array}$ & Diet & & $\begin{array}{l}\text { Days on } \\
\text { exp. diet }\end{array} / \begin{array}{l}\text { Start of } \\
\text { diarrhea }^{1}\end{array}$ & $\begin{array}{l}\text { Days with } \\
\text { diarrhea } \\
\text { before } \\
\text { euthanasia }\end{array}$ & $\begin{array}{c}\text { Age at } \\
\text { eutha- } \\
\text { nasia, } \\
\text { days }\end{array}$ & $\begin{array}{c}\text { Clinical } \\
\text { status at } \\
\text { eutha- } \\
\text { nasia } \\
\text { nas }^{2}\end{array}$ \\
\hline 1 & \multirow{6}{*}{ B1 } & & $3 / 3$ & $1 / 3$ & 21 & D \\
\hline 2 & & & $3 / 3$ & $1 / 3$ & 10 & D \\
\hline 3 & & & $9 / 4$ & 5 & 27 & D \\
\hline 4 & & & $9 / 6$ & 3 & 24 & D \\
\hline 5 & & & $17 / 3$ & 12 & 33 & C \\
\hline 6 & & & $17 / 4$ & 11 & 29 & C \\
\hline 7 & \multirow{6}{*}{ B2 } & & $3 / 0$ & 3 & 21 & D \\
\hline 8 & & & $3 / 2$ & 1 & 10 & D \\
\hline 9 & & & $9 / 4$ & 5 & 21 & D \\
\hline 10 & & & $9 / 2$ & 7 & 25 & D \\
\hline 11 & & & $17 / 3$ & 12 & 30 & C \\
\hline 12 & & & $17 / 3$ & 12 & 31 & C \\
\hline 13,14 & B3 & \multirow{2}{*}{ controls } & $5 / 0$ & 0 & 26,18 & $\mathbf{N}$ \\
\hline $17-21$ & WM & & $0 / 0$ & 0 & $17-23$ & $\mathbf{N}$ \\
\hline
\end{tabular}

1 days after start of exp. diet.

$2 \mathrm{~N}=$ normal, i.e. no diarrhea; $\mathrm{D}=$ diarrhea; $\mathrm{C}=$ convalescent.

approximate localization of the samples for all the calves given in percentage of the distance between the pylorus and the ileocecal opening was: middle duodenum (d2): 1, middle jejunum $(\mathrm{mj})$ : $50-65$, posterior jejunum 1 (pj1): 75-85, posterior jejunum 3 (pj3) : 90—95 and ileum: 99. The methods for light microscopy (LM), including frozen sections, morphometry, and scanning and transmission electron microscopy (SEM and TEM), have been reported previously (Landsverk 1979, 1981a). Additional LM techniques included Gram staining and Macchiavello's stain for chlamydial inclusions.

\section{Microbiologic examinations}

The methods for immunofluorescence on frozen sections and serological examinations for rotavirus will be described elsewhere (Landsverk et al. in prep.).

\section{Statistical evaluation}

The data obtained by the morphometric examination were computerized and analyzed according to Duncan's multiple range test. 


\section{RESULTS}

The controls remained healthy throughout their lives. Calves 1-12 seemed healthy during the first week after their arrival at the research station when they were given whole cow's milk. All calves 1-12 developed diarrhea after the introduction of the milk replacers (Table 1 ), the feces being fluid and yellow-white to white in colour; the stools were, however, never blood-stained. With the diarrhea the calves became unthrifty and had a dull hair coat. The appetite was, however, usually good. Calf 9 developed a more severe clinical condition and became apathetic and recumbent. After about 12 days with diarrhea the 4 remaining calves $(5,6,11,12)$ showed clinical improvement. The normal lustre of the hair coat reappeared and the feces became less soft; these calves are later referred to as convalescents.

At necropsy the forestomachs of all the calves were small (200 g empty weight on average) and corresponded in appearance to the pre-ruminant stage. The ruminal mucosa was usually yellow-white and the papillae were conoid, pliable and less than $0.5 \mathrm{~cm}$ in length. The rumen had a greyish watery content and often contained bezoars. Calf 9 showed rumenitis, with grey-red discoloration of the ruminal mucosa in large areas of the ventral part of the rumen.

The diarrheic calves had a varying congestion of the abomasal and intestinal mucosa. Calf 9 showed marked hyperemia and edema of the intestinal wall and mesenterium and marked enlargement of the mesenteric lymph nodes. The small intestinal contens were not conspicuously changed, whereas the contents of the colon corresponded in appearance to that of the feces.

The intestines of the controls had normal LM features. In the diarrheic calves there were changes varying in severity (Table 2). There was a varying but mostly moderate attenuation of epithelial cells covering the villi (Figs. 3, 7). In pronounced cases disorganization of the epithelial cells was seen (Fig. 7). Gram staining revealed large numbers of Gram negative rodshaped bacteria attached to the tips of the villi in the duodenum and the middle jejunum of calf 1 . Oil red 0 staining showed increased occurrence of fat droplets in the epithelial cells of the middle and occasionally in the posterior small intestine, as compared with corresponding sites of the controls. The fat droplets were mostly small, but some large ones were also observed in the actual intestinal segments. The large droplets tended to 


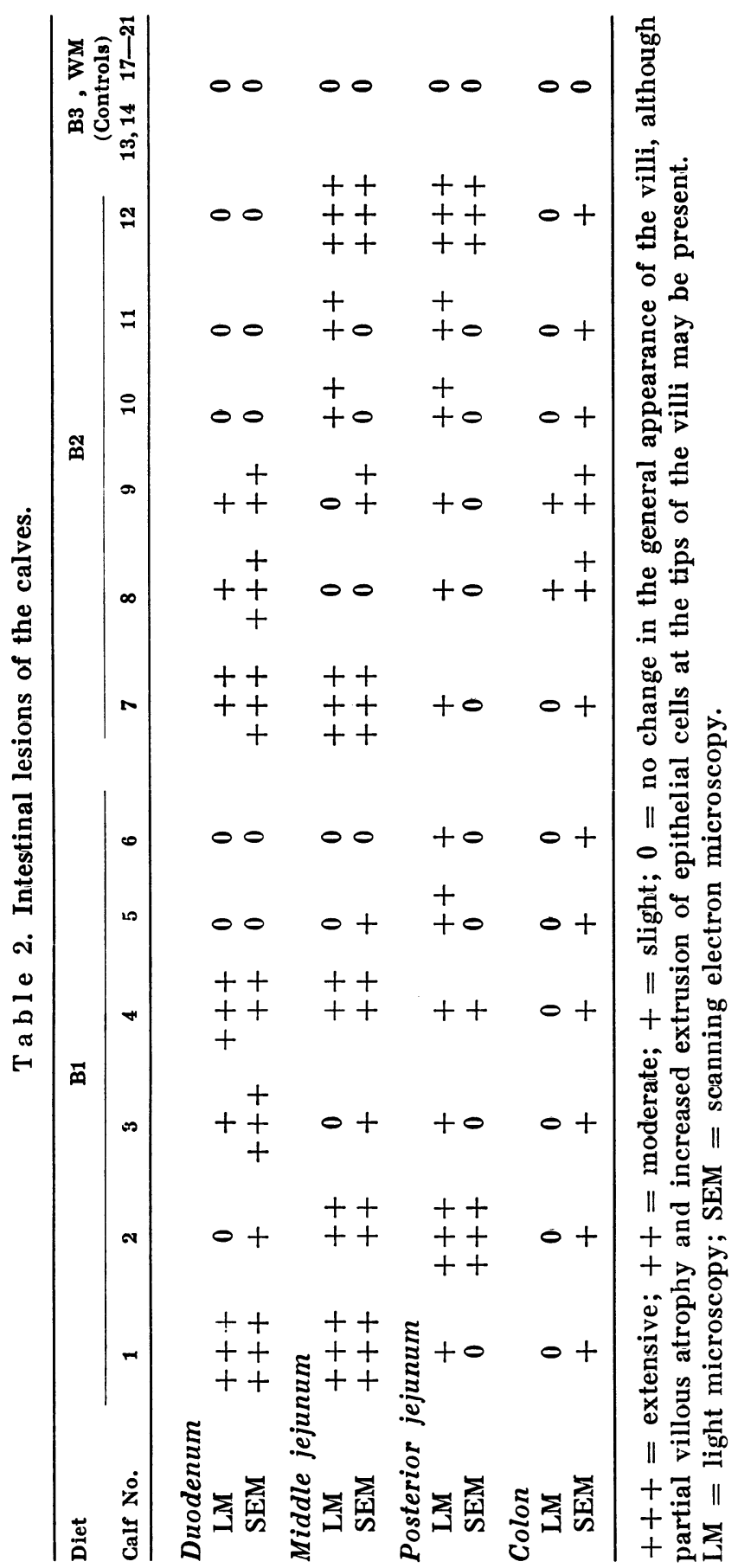


Ta ble 3. Statistical analysis of morphometric data using Duncan's multiple range test. Duodenum (d2).

\begin{tabular}{|c|c|c|c|c|c|c|c|}
\hline \multicolumn{4}{|c|}{ Villi } & \multicolumn{4}{|c|}{ Crypts } \\
\hline $\begin{array}{l}\text { Calf } \\
\text { No. }\end{array}$ & $\begin{array}{l}\text { Clinical } \\
\text { status }^{1}\end{array}$ & $\begin{array}{l}\text { Mean } \\
(\mu \mathrm{m})\end{array}$ & Grouping $^{2}$ & $\begin{array}{l}\text { Calf } \\
\text { No. }\end{array}$ & $\begin{array}{c}\text { Clinical } \\
\text { status }^{1}\end{array}$ & $\begin{array}{l}\text { Mean } \\
(\mu \mathrm{m})\end{array}$ & Grouping \\
\hline 20 & $\mathbf{N}$ & 1211 & $\mathbf{A}$ & 4 & D & 512 & $\mathbf{A}$ \\
\hline 2 & D & 952 & B & 3 & D & 464 & A B \\
\hline 14 & $\mathbf{N}$ & 939 & B & 10 & D & 426 & B \\
\hline 19 & $\mathbf{N}$ & 932 & B & 5 & $\mathbf{C}$ & 420 & B \\
\hline 21 & $\mathbf{N}$ & 915 & B & 7 & D & 373 & $\mathbf{C}$ \\
\hline 13 & $\mathbf{N}$ & 903 & B & 12 & C & 370 & $\mathbf{C}$ \\
\hline 10 & D & 889 & B & 11 & $\mathbf{C}$ & 350 & C. D \\
\hline 18 & $\mathbf{N}$ & 880 & B & 2 & D & 346 & C D \\
\hline 17 & $\mathbf{N}$ & 863 & B & 8 & D & 330 & C D \\
\hline 5 & C & 712 & C & 18 & $\mathbf{N}$ & 313 & E D \\
\hline 11 & $\mathbf{C}$ & 707 & C & 1 & D & 312 & E D \\
\hline 7 & D & 569 & D & 17 & $\mathbf{N}$ & 307 & E D F \\
\hline 3 & D & 500 & D E & 9 & D & 294 & E D F \\
\hline 12 & $\mathbf{C}$ & 499 & D E & 21 & $\mathbf{N}$ & 273 & E G F \\
\hline 8 & D & 480 & $\mathrm{E}$ & 6 & C & 267 & E G F H \\
\hline 6 & C & 477 & $\mathrm{E}$ & 19 & $\mathbf{N}$ & 262 & G F H \\
\hline 9 & D & 425 & F E & 20 & $\mathbf{N}$ & 229 & I G H \\
\hline 4 & D & 376 & F G & 13 & $\mathbf{N}$ & 220 & I H \\
\hline 1 & D & 330 & $\mathbf{G}$ & 14 & $\mathbf{N}$ & 208 & I \\
\hline
\end{tabular}

$1 \mathrm{~N}=$ normal, no diarrhea; $\mathrm{D}=$ diarrhea; $\mathrm{C}=$ convalescent.

2 means with the same letter are not significantly different $(P>0.05)$.

occupy great parts of the epithelial cell cytoplasm and sometimes caused a displacement of the nucleus. Migration of neutrophils to the crypt lumen was regularly observed (Fig. 4). The lamina propria showed an increase of mononuclear cells, including lymphocytes and macrophages, and there was infiltration of varying numbers of neutrophils, eosinophils and cells with ovoid nuclei and eosinophilic granules, possibly globule leukocytes.

Whereas the convalescent calves generally showed milder lesions with respect to the above features, both the convalescents and diarrheic calves had advanced lesions of the "pseudovilli" (syn. domes or lymphoid villi) over Peyer's patches, the most prominent being fusion of the "pseudovilli" with ordinary villi. Chlamydia-like red inclusion bodies were found in "pseudovillous" epithelial cells of calves 3, 5, 11, 12, using Macchiavello's stain. A more detailed description of the lesions of the "pseudovilli" is given in another report (Landsverk 1981c). 
Thor Landsverk: Pathomorphology of the Intestinal Mucosa in Diarrheic Calves

Fig u r e 1. Scanning electron micrograph, middle duodenum (d2), control calf $(21)$. Normal tongue-shaped villi. $\times 150$.

Fig u r e 2. Scanning electron micrograph, middle duodenum (d2), diarrheic calf (7). Villi are stunted. Note the variation in villous diameter. Debris (arrows) sticks to the villous surface. $\times 150$.

Figure 3. Middle duodenum (d2), diarrheic calf (1). Villi are atrophied, fused (arrows) and crypts are hyperplastic. Moderate attenuation of apical villous epithelial cells. $\mathrm{HE}, \times 100$.

Fig u r e 4. Middle duodenum (d2), diarrheic calf (9). Migration of neutrophils to the crypt lumen. HE, $\times 390$.

F igu re 5. Scanning electron micrograph, middle jejunum (mj), control calf $(20)$. Normal finger-shaped villi. $\times 150$.

F i g u r e 6. Scanning electron micrograph, middle jejunum, diarrheic calf $(7)$. The surface of the villi is convoluted. $\times 150$.

F i g u r e 7. Middle jejunum, diarrheic calf (4). The epithelial cells show decreased cell height and are irregularly organized. Increased cellularity in the lamina propria. $\mathrm{HE}, \times 360$.

F ig u r e 8. Scanning electron micrograph, middle jejunum, diarrheic calf (1). Masses of rod-shaped bacteria cover the villous surface. $\times 1,000$.

F i g u r e 9. Immunofluorescence, FITC rotavirus conjugate, middle jejunum, diarrheic calf (1). The villus is cut obliquely. Positive fluorescence in the apical villous epithelial cells. $\times 400$.

Fig u r e 10. Scanning electron micrograph, posterior jejunum (pj3), diarrheic calf (9). The general appearance of the villus is not markedly different from the controls, but there are many protruding epithelial cells at the villous tip with bristle microvilli, probably degenerated epithelial cells being extruded. $\times 600$.

F ig u r e 11. Scanning electron micrograph, posterior jejunum (pj3), control calf $(20)$. The apex of the villus has a few protruding epithelial cells with bristle microvilli, probably degenerated cells being extruded. One cell or cell fragment is apparently almost released (arrow). $\times 3,000$. 
F i g u r e 12. Scanning electron micrograph, posterior jejunum (pj3), diarrheic calf (4). The number of protruding cells is larger than in the control (Fig. 11). The surface of the protruding epithelial cells is either flattened or contains bristle microvilli. Arrows indicate membrane ruptures. $\times 3,000$.

F ig u r e 13. Scanning electron micrograph, posterior jejunum (pj3), convalescent calf $(12)$. Villi are atrophied and fused. $\times 150$.

F i g u r e 14. Scanning electron micrograph, posterior jejunum (pj3), diarrheic calf (2). Fusion with formation of bridges (B) between apposed villi. $\times 1,000$.

F i g u r e 15. Scanning electron micrograph, colon, control calf (20). Smooth mucosa with narrow clefts. $\times 200$.

Figure 16. Scanning electron micrograph, colon, diarrheic calf (9). Irregular mucosa with protruding epithelial cells. $\times 300$.

F i g u re 1 7. Scanning electron micrograph, area adjacent to Fig. 16. Bulging epithelial cells, probably in the process of being extruded. The protruding cells have a sparse microvillous equipment. Arrow indicates membrane rupture. $\times 3,000$.

Figure 18. Transmission electron micrograph, ileum, diarrheic calf (3). "Pseudovillous" epithelial cells with different stages of chlamydia within cytoplasmic vacuoles; elementary bodies (EB), condensing bodies $(\mathrm{CB})$ and reticulate bodies $(\mathrm{RB}) . \mathrm{DB}=$ dense bodies, $\mathrm{N}=$ host cell nuclei. $\times 12,000$.

F igure 19. Transmission electron micrograph, middle jejunum, diarrheic calf (1). Apical villous epithelial cell with viral particles within dilated endoplasmic reticulum (arrows). The particles consist of a dense nucleoid surrounded by a less dense outer coat. $\mathrm{G}=$ Golgi's apparatus, $\mathrm{N}=$ host cell nucleus. $\times 51,000$. 

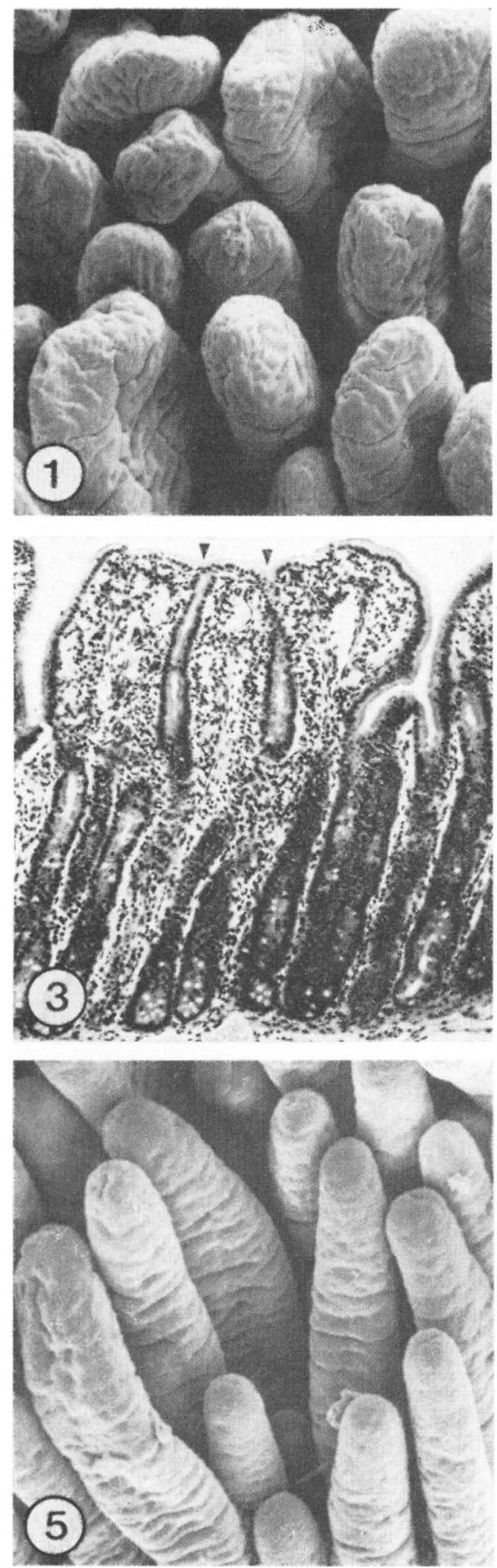
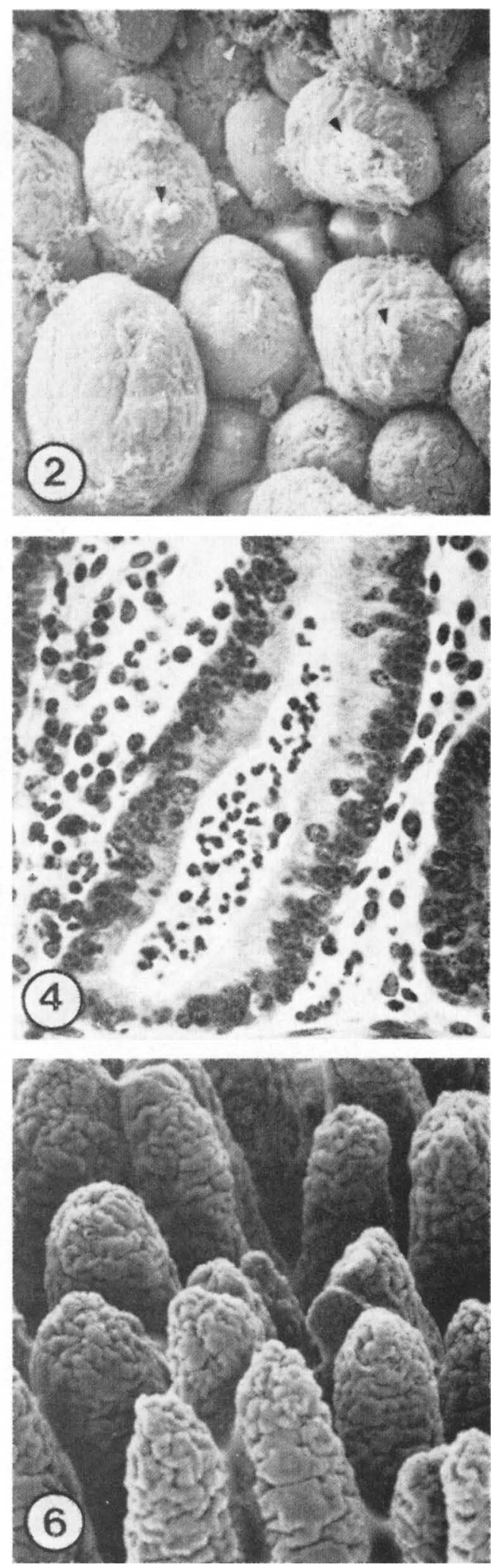

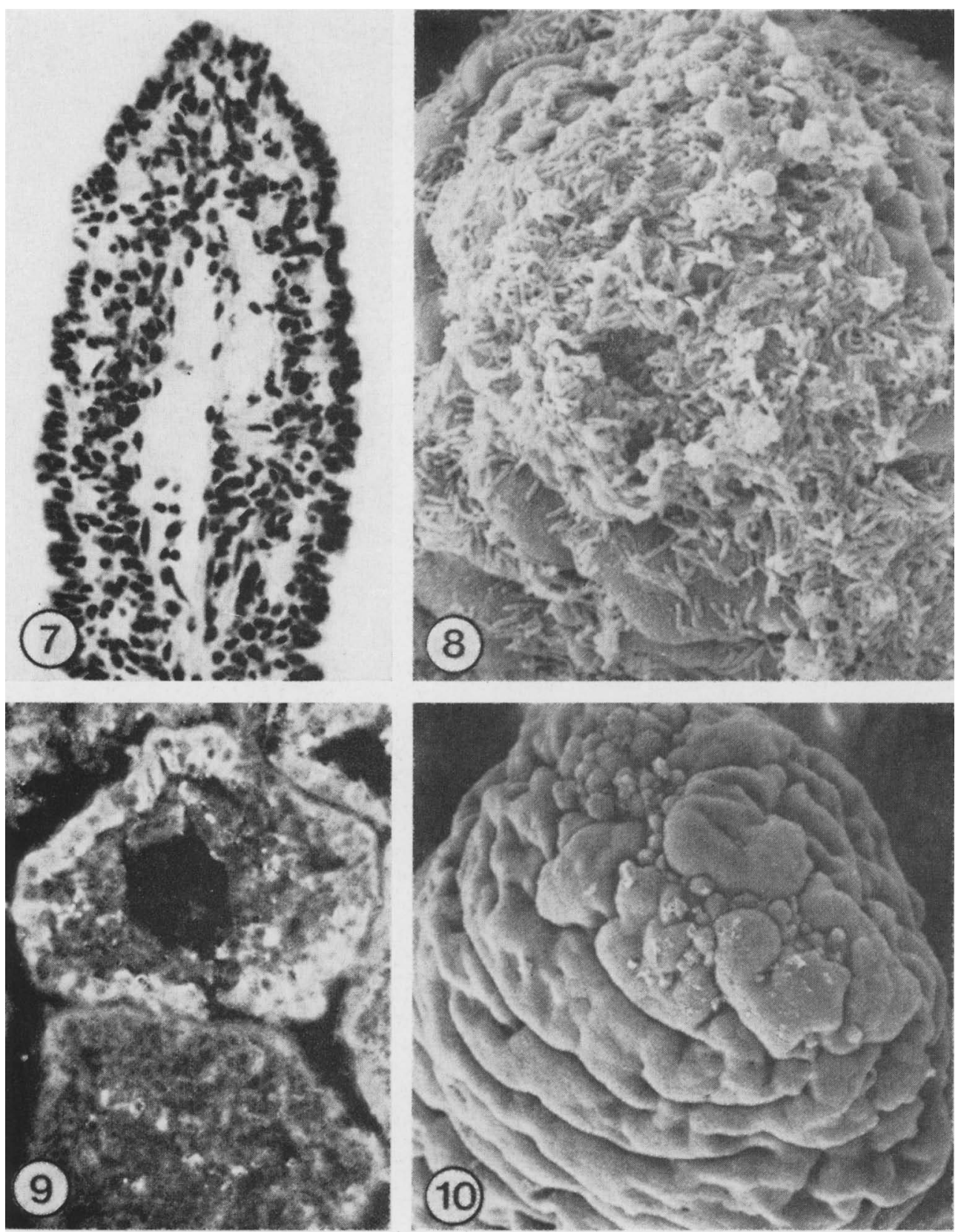

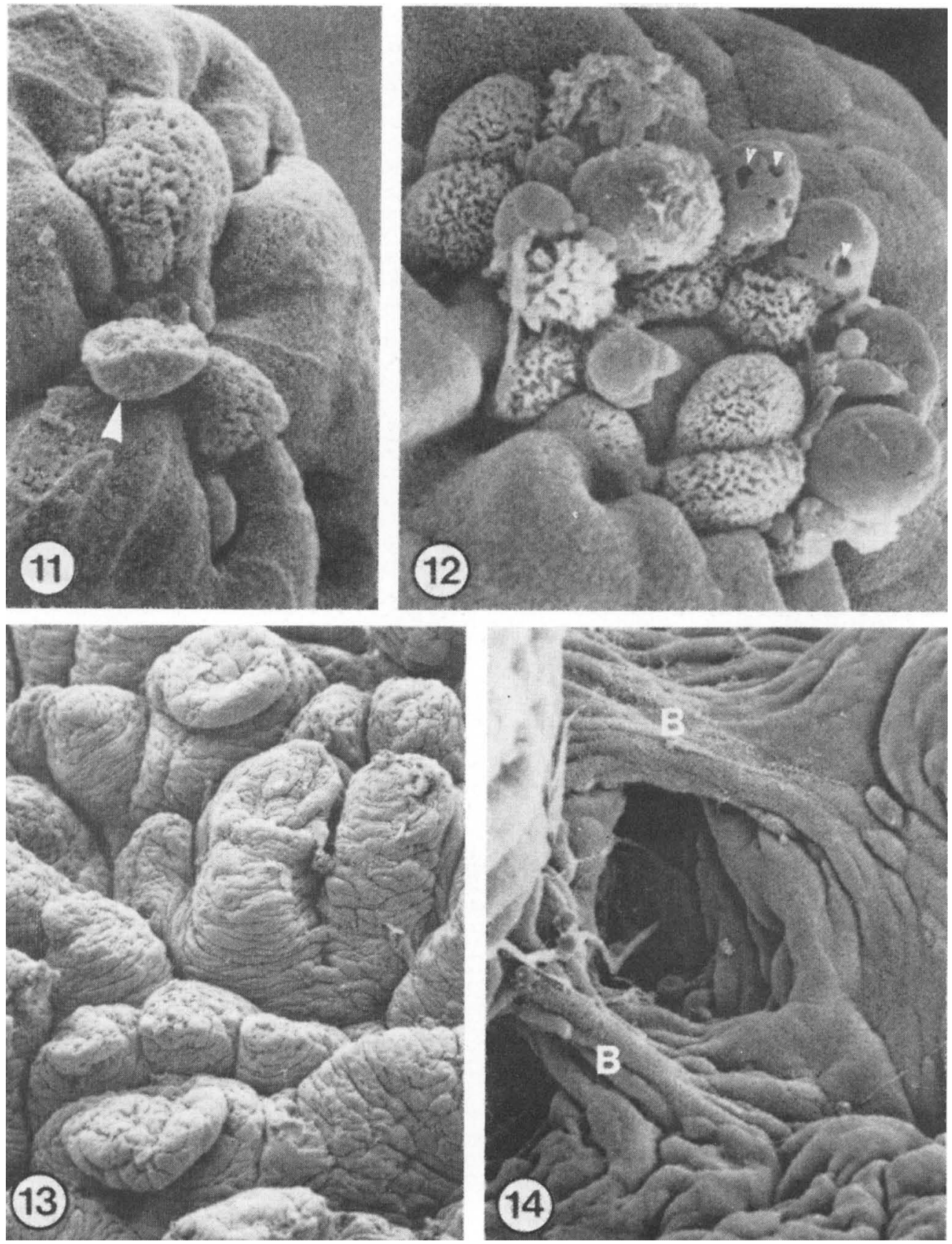

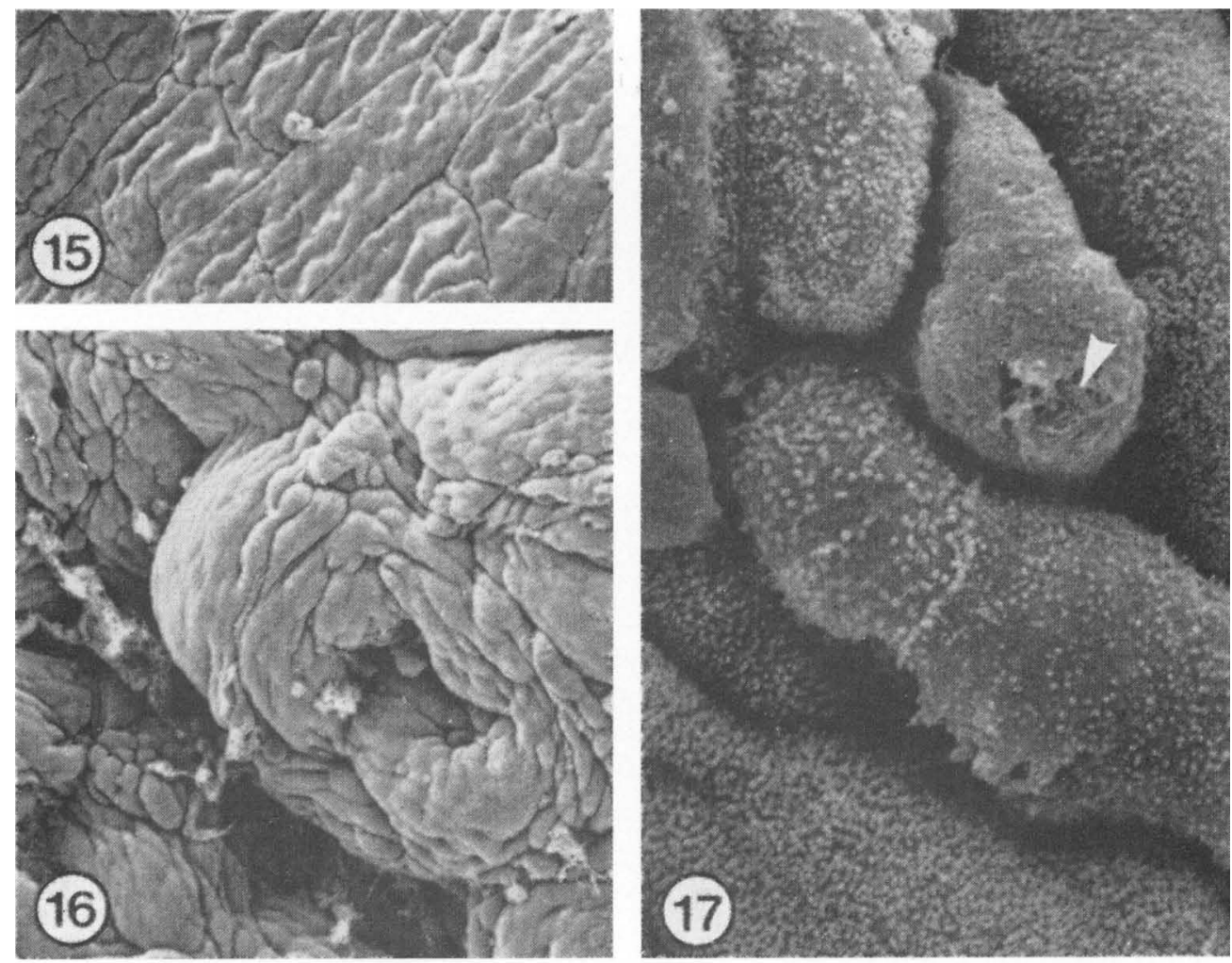

17

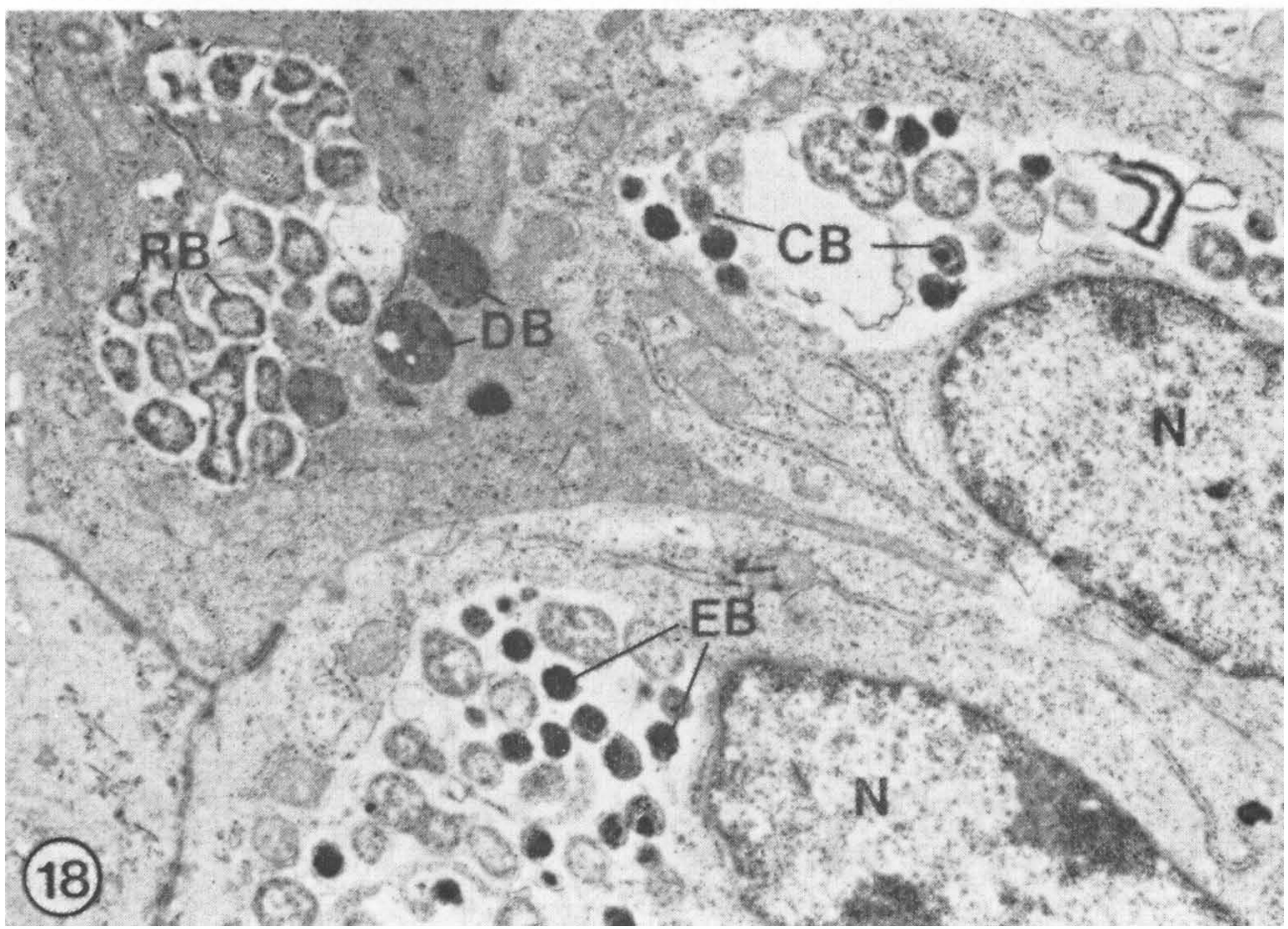




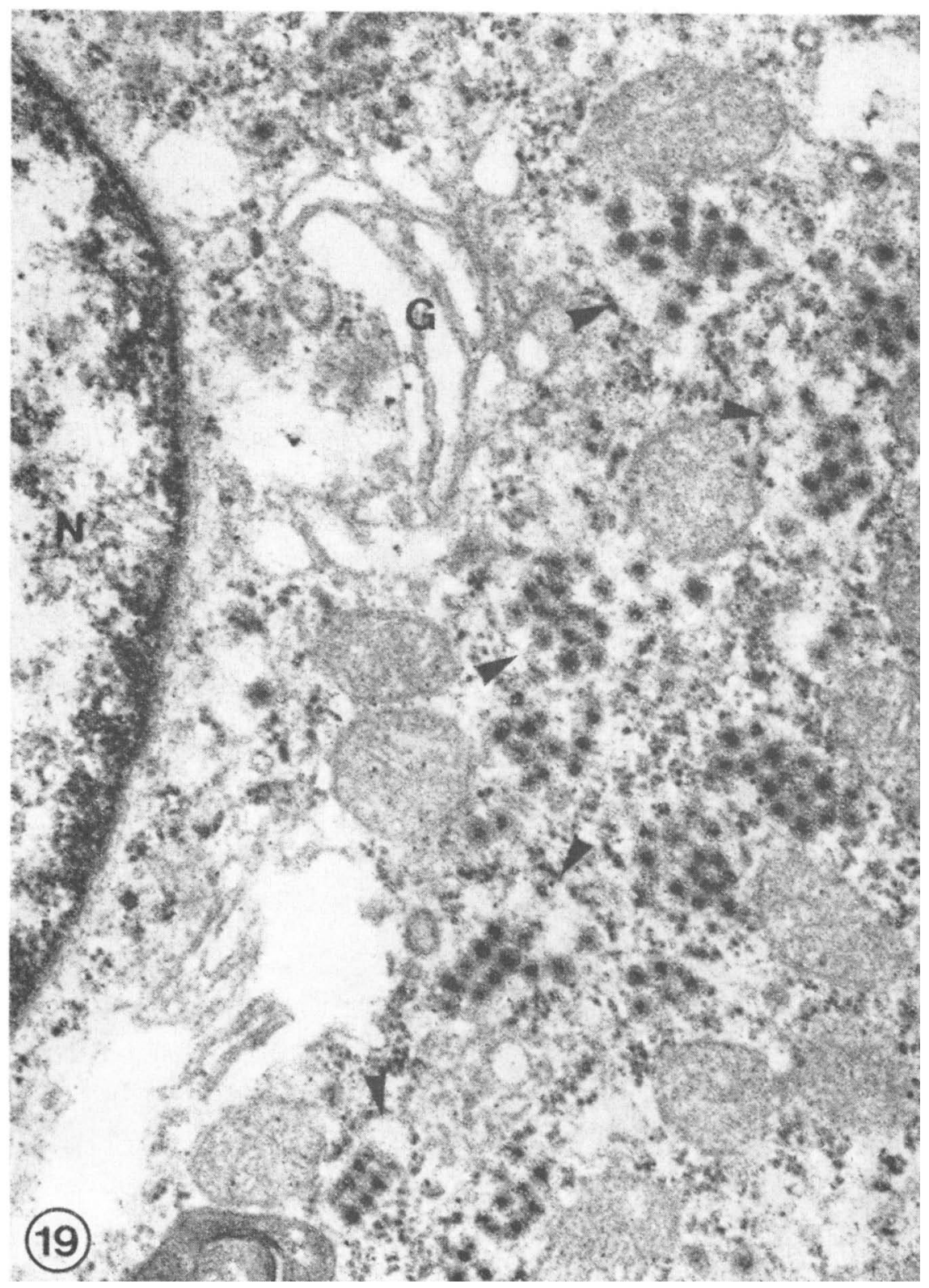


T a b l e 4. Statistical analysis of morphometric data using Duncan's multiple range test. Posterior jejunum (pj3).

\begin{tabular}{|c|c|c|c|c|c|c|c|}
\hline \multicolumn{4}{|c|}{ Villi } & \multicolumn{4}{|c|}{ Crypts } \\
\hline $\begin{array}{l}\text { Calf } \\
\text { No. }\end{array}$ & $\underset{\text { status }^{1}}{\text { Clinical }}$ & $\begin{array}{l}\text { Mean } \\
(\mu \mathrm{m})\end{array}$ & Grouping ${ }^{2}$ & $\begin{array}{l}\text { Calf } \\
\text { No. }\end{array}$ & $\begin{array}{c}\text { Clinical } \\
\text { status }\end{array}$ & $\begin{array}{l}\text { Mean } \\
(\mu \mathrm{m})\end{array}$ & Grouping ${ }^{2}$ \\
\hline 7 & D & 755 & $\mathbf{A}$ & 11 & C & 506 & $\mathbf{A}$ \\
\hline 8 & D & 665 & B & 3 & D & 482 & $\mathbf{A}$ \\
\hline 19 & $\mathbf{N}$ & 507 & C & 12 & C & 455 & A B \\
\hline 20 & $\mathbf{N}$ & 462 & C D & 4 & D & 418 & C B \\
\hline 17 & $\mathbf{N}$ & 457 & C D & 7 & D & 388 & C D \\
\hline 5 & C & 447 & C D E & 2 & D & 385 & C D \\
\hline 13 & $\mathbf{N}$ & 426 & F D E & 10 & D & 366 & E D \\
\hline 1 & D & 424 & F D E & 8 & D & 322 & E F \\
\hline 21 & $\mathbf{N}$ & 421 & F D E & 1 & D & 310 & $\mathbf{F}$ \\
\hline 14 & $\mathbf{N}$ & 409 & F D E G & 14 & $\mathbf{N}$ & 298 & G F \\
\hline 18 & $\mathbf{N}$ & 408 & F D E G & 6 & C & 296 & G F \\
\hline 2 & D & 396 & F D E G & 5 & C & 292 & G F H \\
\hline 10 & D & 375 & F H E G & 20 & $\mathbf{N}$ & 276 & G F H I \\
\hline 6 & C & 374 & F H E G & 9 & D & 272 & G F H I \\
\hline 11 & $\mathbf{C}$ & 362 & F H G & 21 & $\mathbf{N}$ & 270 & G F H I \\
\hline 9 & D & 352 & F H G & 13 & $\mathbf{N}$ & 254 & G H I \\
\hline 4 & D & 339 & H G & 19 & $\mathbf{N}$ & 240 & H I \\
\hline 3 & D & 309 & $\mathrm{H}$ & 18 & $\mathbf{N}$ & 239 & I \\
\hline 12 & C & 237 & I & 17 & $\mathbf{N}$ & 223 & I \\
\hline
\end{tabular}

$1 \mathrm{~N}=$ normal, no diarrhea; $\mathrm{D}=$ diarrhea; $\mathrm{C}=$ convalescent.

2 means with the same letter are not significantly different $(P>0.05)$.

In the cecum and colon of calves $1-12$ there was an increase of mononuclear cells in the lamina propria. Occasionally surface epithelial cells were attenuated or were apparently being desquamated.

Morphometric examination showed a varying villous atrophy and crypt elongation in the diarrheic and convalescent calves (Figs. 20, 21, Tables 3, 4).

The controls showed normal features by SEM (Figs. 1, 5, 11). Calves 1-12 showed varying degrees of changes (Table 2). The villi were mostly blunt (Fig. 2); advanced lesions included an irregular convoluted surface (Fig. 6). Groups of protruding epithelial cells were seen at the villous tips, particularly in the posterior small intestine (Figs. 10, 12). These cells frequently showed signs of degeneration, including loss of microvilli, and were apparently in the process of being extruded. This trait was in part interpreted as normal extrusion of senescent epithelial 


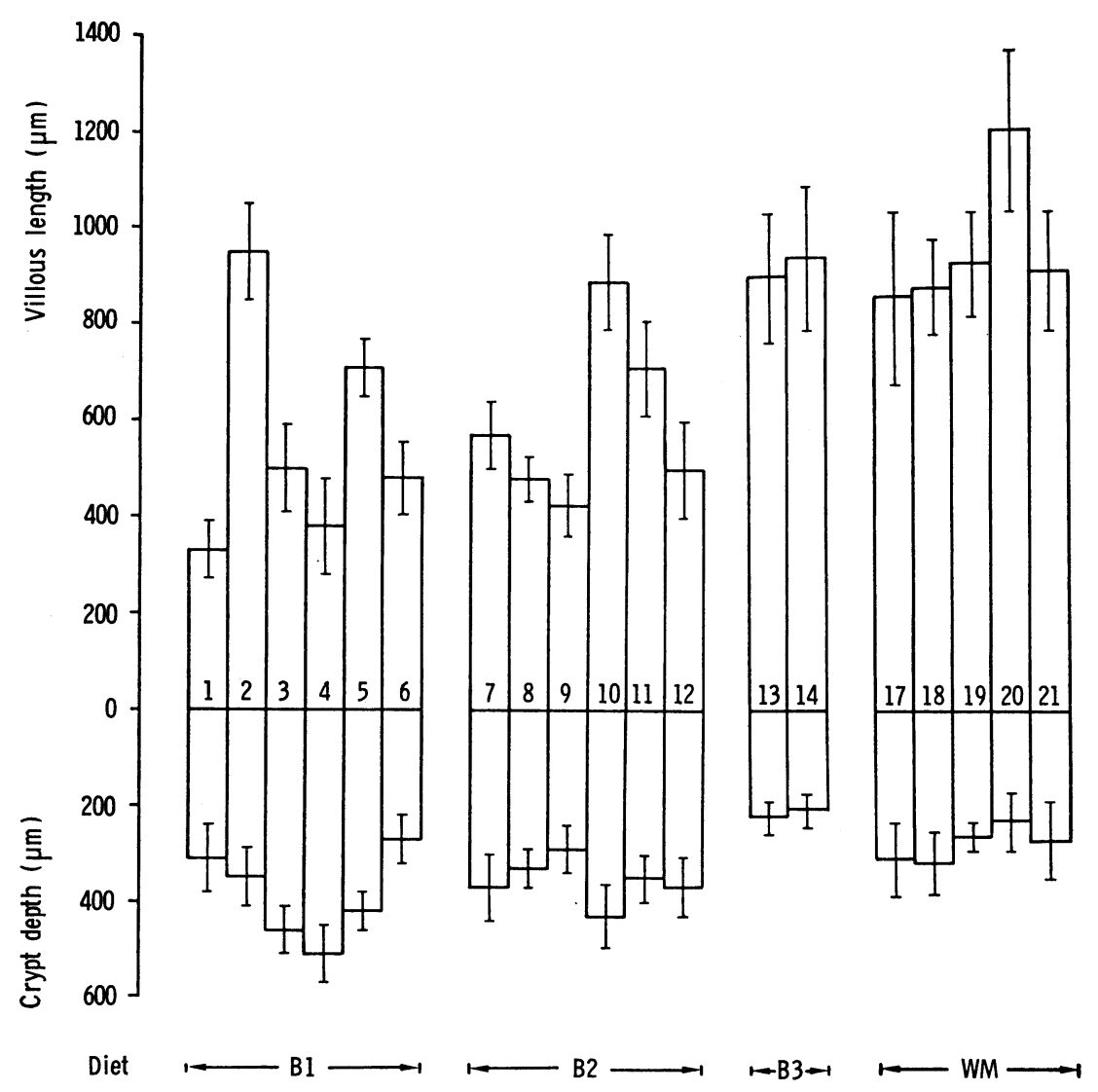

Fig u re 20 . Mucosal measurements of middle duodenum (d2) with standard deviation indicated.

cells, since corresponding phenomena were also found in the controls; in the latter, however, substantially fewer cells were affected (Fig. 11). Denuded areas of the lamina propria were never observed in the villi. Prominent atrophy and fusion of villi over Peyer's patches were found in calves 2 and 12 (Figs. 13, 14). Masses of rod-shaped bacteria were seen on the surface of villous tips in the duodenum and middle jejunum of calf 1 (Fig. 8), while small groups of such bacteria were found on the surface of the villi in the posterior jejunum of calf 2 . The colonic mucosa of calves 1-12 had a more uneven surface than the controls (Figs. 15, 16). In calves 8 and 9 protrusion of epithelial cells deficient in microvillous equipment was seen (Fig. 17). These cells were situated halfway between the crypt openings, i.e. in 


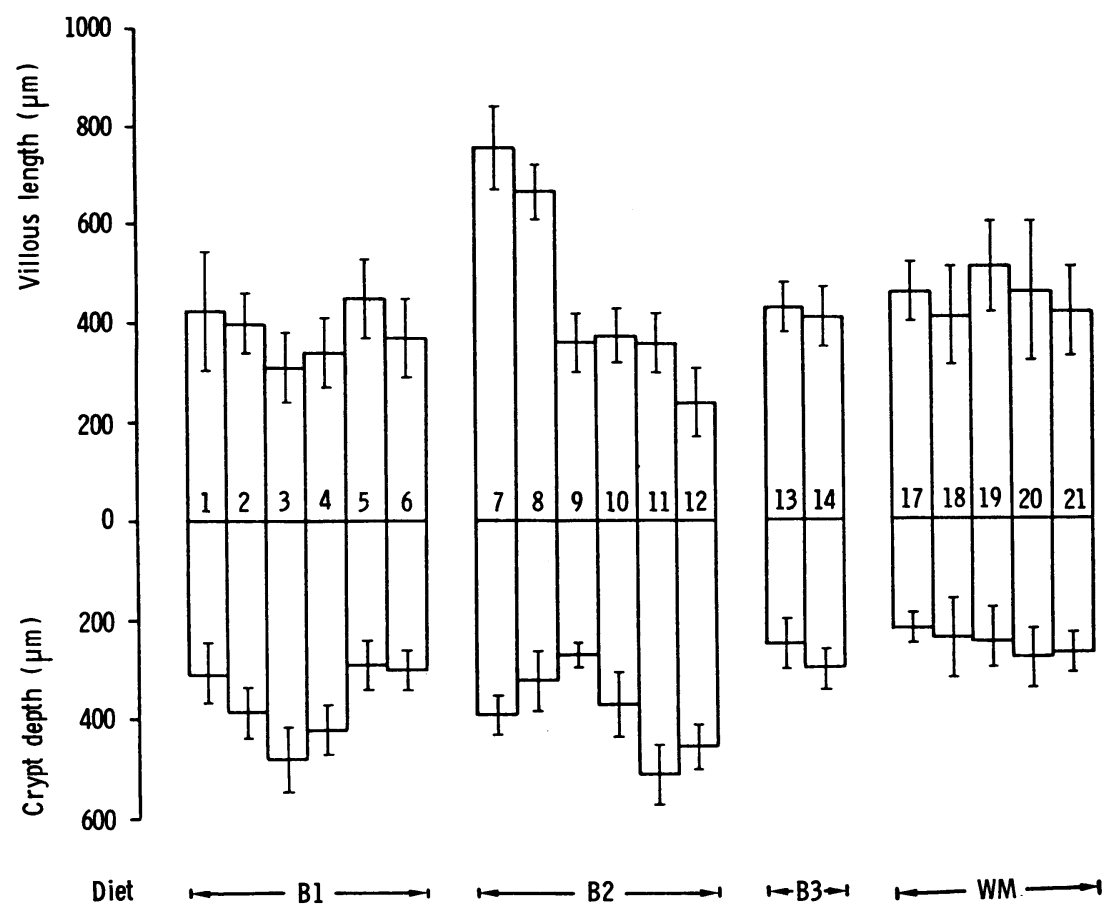

Figure 21. Mucosal measurements of posterior jejunum (pj3) over Peyer's patches with standard deviation indicated.

the zone where normal extrusion of senescent epithelial cells is to be expected (Specht 1977).

The result of the TEM studies of "pseudovilli" will be dealt with in greater detail elsewhere (Landsverk 1981c). In this context the demonstration of chlamydia may be pointed out. In "pseudovillous" epithelial cells of the calves showing inclusions by Macchiavello's stain, micro-organisms were found within membrane-enclosed vacuoles (Fig. 18). The micro-organisms were in different stages of development. Reticulate, condensing and elementary bodies were seen, the morphology corresponding to that suggested as specific for chlamydia (Doughri et al. 1973, Todd et al. 1976). Specimens immunofluorescence-positive for rotavirus (se below) had viral particles within dilated cisterna of rough endoplasmic reticulum in apical villous epithelial cells (Fig. 19). The viral particles were about $65 \mathrm{~nm}$ in diameter and had a dense nucleoid surrounded by a less dense outer coat, the morphology corresponding to that of rotavirus (Stair et al. 1973). 
Serological studies indicated the probability of a widespread rotavirus infection among calves $1-12$, the serum titers at euthanasia showing consistently higher values in the convalescents $(1: 40-1: 320)$ than in the calves euthanized $1 / 3-3$ days after the start of the diarrhea $(<1: 10-1: 10)$ and being similar to or higher than in the case of those euthanized 5-7 days after the start of the diarrhea $(1: 20-1: 40)$. Studies of frozen intestinal sections showed positive immunofluorescence for rotavirus in intestinal villi of calves 1 and 8 (Fig. 9). Bacteriological examination showed large numbers of coliforms, probably Escherichia coli, in the middle jejunum of calf 1 . Calf 9 had large numbers of pseudomonas in the rumen and in the middle and posterior small intestine. A more detailed description of the microbiologic results will be given elsewhere (Landsverk et al., in prep.).

\section{DISCUSSION}

The most prominent pathomorphologic feature of the present enteric condition was villous atrophy and crypt elongation. This mode of intestinal reaction has been associated with influences causing destruction of villous epithelial cells, in particular certain viral infections (Kent \& Moon 1973). Viral tropism for villous epithelial cells characterizes rota- and coronavirus infections in calves (Mebus et al. 1971, 1973, Morin et al. 1974, Doughri \& Storz 1977). But a variety of other agents, including enteropathogenic strains of Escherichia coli and chlamydia, have been associated with villous stunting (Doughri et al. 1974, Pearson et al. 1978). The intestinal lesions found in the present calves are therefore in good accordance with the indicated rotavirus and chlamydial infections. These infections were presumed to be the major determinants of the present enteric condition, although coliforms, probably Escherichia coli, and pseudomonas may have contributed in two cases. The change of diet possibly had a provoking influence (Landsverk et al., in prep.).

Elongation of crypts appears to be an expression of crypt hyperplasia resulting in an increased production of epithelial cells (Rijke et al. 1976). Hyperplasia of crypts has been thought to be due to increased demands for epithelial cells in situations with enhanced loss of villous epithelial cells, and so a feed-back mechanism has been suggested (Rijke et al.). The present villous atrophy seemed to be connected with an increase in the number 
of necrotic cells at the tips of the villi, in the area where the normal extrusion of cells is supposed to occur (Padykula 1962). This trait appeared to be rather a general one and was not only confined to the calves and sites where rotavirus and chlamydia were demonstrated. Although these agents probably caused an increase in the occurrence of necrotic cells, other factors, including bacteria and their toxins, may have contributed. Apparently, the senescent epithelial cells at the tips of the villi were most vulnerable to the noxious influences.

Although groups of necrotic epithelial cells were frequently observed at the tips of the villi in the present calves, villous denudation was never observed. There seems to be some discrepancy concerning denudation of lamina propria of villi during infectious enteric conditions, but these results are obviously in accordance with those of Pearson et al. (1978). Villous denudation may be less common than usually thought, but may appear as an important postmortem artefact, making sampling of specimens under general anaesthesia advantageous or even necessary (Pearson \& Logan 1978, Landsverk 1979). It seems that the epithelial gaps formed during extrusion of necrotic cells are quickly filled by stretching and fusing of neighbouring epithelial cells. The stretching of epithelial cells, apparently representing an effort to reach neighbouring cells and cover denuded areas, may be the actual mechanism responsible for the decrease in height of the epithelium seen in cases with extensive epithelial cell extrusion. The fusing of neighbouring villi may be relative to these possibly inherent capacities of the epithelial cells.

Occurrence of large fat droplets in villous epithelial cells is claimed to be a characteristic feature of coronavirus infection in puppies (Keenan et al. 1976) and viral enteritis of mink (Krunajevic 1970). Large fat droplets are, however, a common finding in duodenal epithelial cells of healthy calves (Landsverk 1979). In the present diarrheic calves there seemed to be some change in the normal pattern of fat absorption, since increased amounts of fat, including some large fat droplets, were found in posterior intestinal segments. The feature might be caused by decreased absorption of fat in the anterior segments. A change in the distribution of fat absorption between various intestinal segments has also been described in piglets with white scours (Mowen 1972).

Enhanced migration of neutrophils to the intestinal propria 
and crypt lumen was a conspicuous feature of the present intestinal changes. Corresponding neutrophil migration has been described in colibacillosis of calves (Bellamy \& Acres 1979). Although the intestinal tract is normally the principal site of granulocyte elimination (Teir \& Rytömaa 1966), enhanced migration of neutrophils has been shown to be a specific antibodymediated immune response (Bellamy \& Nielsen 1974).

Except for the presence of rotavirus antigen and bacteria on the villous surface, there were no major differences between calves euthanized at the beginning of the diarrheic condition and about a week after the start of the diarrhea. The convalescent calves showed an incomplete morphologic recovery, lesions being found particularly in the posterior small intestine. In 3 out of 4 convalescent calves a conspicuous chlamydial infection was found, associated with lesions over Peyer's patches, the most outstanding feature being fusion of "pseudovilli" with ordinary villi. A further examination of these lesions and a discussion on their possible implications for the course of the disease are the subjects of another report (Landsverk 1981c).

\section{ACKNOWLEDGEMENTS}

I wish to thank Peter Möller A/S for the use of Holt Research Station and for practical assistance with the experiment. I am grateful to Professor J. Storz, Department of Microbiology, College of Veterinary Medicine, Colorado State University, Fort Collins, USA, for his opinion on the agents demonstrated in one of the transmission electron micrographs (Fig. 18). I am also indebted to Mr Mönnes and the Computing Centre, Agricultural University of Norway for valuable assistance with the statistical calculations, the Department of Anatomy, Dental Faculty, University of Oslo for the use of its scanning electron microscope, and S. Stölen, engineer, for operation of the same.

\section{REFERENCES}

Appleman, R. D. \& F. G. Owen: Breeding, housing and feeding management. J. Dairy Sci. 1975, 58, 447-464.

Bellamy, J. E. C. \& N. O. Nielsen: Immune-mediated emigration of neutrophils into the lumen of the small intestine. Inf. Immun. $1974,9,615-619$.

Bellamy, J. E. C. \& S. D. Acres: Enterotoxigenic colibacillosis in colostrum-fed calves: Pathologic changes. Amer. J. vet. Res. 1979, 40, $1391-1397$.

Doughri, A. M., K. P. Altera, J. Storz \& A. K. Eugster: Ultrastructural changes in the chlamydia-infected ileal mucosa of newborn calves. Vet. Path. 1973, 10, 114-123. 
Doughri, A. M., S. Young \& J. Storz: Pathologic changes in intestinal chlamydial infection of newborn calves. Amer. J. vet. Res. 1974, $35,939-944$.

Doughri, A. M. \& J. Storz: Light and ultrastructural pathologic changes in intestinal coronavirus infection of newborn calves. Zbl. Vet. Med. B. 1977, 24, 367-385.

Husband, A. J., M. R. Brandon \& A. K. Lascelles: Absorption and endogenous production of immunoglobulins in calves. In W. A. Hemmings: Antigen Absorption by the Gut. MTP Press Ltd., Lancaster 1978, p. 93-107.

Keenan, K. P., H. R. Jervis, R. H. Marchwicki \& L. N. Binn: Intestinal infection of neonatal dogs with canine coronavirus 1-71: Studies by virologic, histologic, histochemical, and immunofluorescent techniques. Amer. J. vet. Res. 1976, 37, 247-256.

Kent, T. H. \& H. W. Moon: The comparative pathogenesis of some enteric diseases. Based on cases presented at the 22nd annual seminar of the American College of Veterinary Pathologists. Vet. Path. 1973, 10, 414-469.

Krunajevic, T.: Experimental virus enteritis in mink. A pathologicanatomical and electron microscopical study. Acta vet. scand. 1970, 11, Suppl. 30.

Laksesvela, B., P. Slagsvold \& T. Landsverk: Indigestion in young calves. III. The influence of powders from heat-treated skimmilk and whey. Acta vet. scand. 1978, 19, 159-165.

Landsverk, $T$.: The gastrointestinal mucosa in young milk-fed calves. A scanning electron and light microscopic investigation. Acta vet. scand. $1979,20,572-582$.

Landsverk, T.: The epithelium covering Peyer's patches in young milk-fed calves. An ultrastructural and enzyme histochemical investigation. Acta vet. scand. 1981 a, 22, 198-210.

Landsverk, T.: An enzyme histochemical investigation of the intestinal mucosa in diarrheic calves. Acta vet. scand. $1981 \mathrm{~b}, 22$, $449-458$.

Landsverk, T.: Peyer's patches and the follicle-associated epithelium in diarrheic calves. Pathomorphology, morphometry and acid phosphatase histochemistry. Acta vet. scand. $1981 \mathrm{c}, 22,459-$ 471.

Landsverk, $T$. et al.: In prep.

Mebus, C. A., E. L. Stair, N. R. Underdahl \& M. J. Twiehaus: Pathology of neonatal calf diarrhea induced by a reo-like virus. Vet. Path. $1971,8,490-505$.

Mebus, C. A., E. L. Stair, M. B. Rhodes \& M. J. Twiehaus: Pathology of neonatal calf diarrhea induced by a coronavirus-like agent. Vet. Path. 1973, 10, 45-64.

Morin, M., P. Lamothe, A. Gagnon \& R. Malo: A case of viral neonatal calf diarrhea in a Quebec dairy herd. Canad. J. comp. Med. 1974, 38, 236-242.

Mowen, J. M. V. M.: White Scours in Piglets at Three Weeks of Age. Proefschrift, Rotterdam 1972.

Padykula, $H$. A.: Recent functional interpretations of intestinal morphology. Fed. Proc. 1962, 21, 873-879. 
Pearson, G. R. \& E. F. Logan: The rate of development of post mortem artefact in the small intestine of neonatal calves. Brit. J. exp. Path. 1978, 59, 178-182.

Pearson, G. R., M. S. McNulty \& E. F. Logan: Pathological changes in the small intestine of neonatal calves with enteric colibacillosis. Vet. Path. 1978, 15, 92-101.

Rijke, R. P. C., W. R. Hanson, H. M. Plaisier \& J. W. Osborne: The effect of ischemic villus cell damage on crypt cell proliferation in the small intestine. Evidence for a feedback control mechanism. Gastroenterology 1976, 71, 786-792.

Roy, J. H. B.: Problems in the nutrition of the preruminant calf. Proc. Nutr. Soc. 1974, 33, 79-86.

Specht, W.: Morphology of the intestinal wall. Its mucous membrane under normal and experimental conditions. In M. Kramer and F. Lauterbach: Intestinal Permeation. Proc. 4. Workshop Conf. Schloss Reisenburg, Excerpta Medica, Amsterdam 1977, p. 4-40.

Stair, E. L., C. A. Mebus, M. J. Twiehaus \& N. R. Underdahl: Neonatal calf diarrhea. Electron microscopy of intestine infected with a reovirus-like agent. Vet. Path. 1973, 10, 155-170.

Teir, H. \& T. Rytömaa: Elimination of granulocytes in the intestinal tract and its pathological consequences. In E. Bajusz and G. Jasmin: Methods and Achievements in Experimental Pathology, vol. 1. S. Karger, Basel and New York 1966, p. 639-676.

Todd, W. J., A. M. Doughri \& J. Storz: Ultrastructural changes in host cellular organelles in the course of the chlamydial developmental cycle. Zbl. Bakt. Hyg. I. Abt. Orig. A 1976, 236, 359-373.

\section{SAMMENDRAG}

En patomorfologisk unders $\emptyset$ kelse av tarmmukosa hos kalver med diaré.

Tarmmukosa ble unders $\varnothing$ kt hos tolv 2-5 uker gamle kalver med en spontan tarmaffeksjon; 8 viste diaré og 4 var rekonvalescenter. Kalvene var fôret med en nærmere definert melkeerstatning. Lysmikroskopi og morfometri viste atrofi av villi og forlengelse av kryptene. Epitelcellene langs villi var lave og i bakre tynntarmsavsnitt inneholdt de mer fett enn normalt. Det forelå en forøket utvandring av nфytrofile granulocytter til lumen av kryptene. Skanning elektron mikroskopi viste butte villi med for $\varnothing k$ et antall nekrotiske celler i avst $\varnothing$ tningssonen på toppen av villi. Rekonvalesentene hadde som regel mildere forandringer, særlig i fremre tarmavsnitt. Hos enkelte kalver ble det påvist rotavirus- og chlamydie-infeksjon, og det ble konkludert med at infeksiøse agens og muligens andre ikke definerte faktorer var årsak til det forøkede henfall av de eldste epitelceller på toppen av villi, noe som resulterte $i$ atrofi av villi og hyperplasi av kryptene.

(Received June 22, 1981).

Reprints may be requested from: T. Landsverk, the Department of Pathology, Veterinary College of Norway, P.O. Box 8146, Dep., Oslo 1, Norway. 